\title{
AKT1S1 Gene
}

National Cancer Institute

\section{Source}

National Cancer Institute. AKT1S1 Gene. NCI Thesaurus. Code C101614.

This gene plays a role in the regulation of mTOR signaling. 